\section{Bryozoan Research}

Sixteen zoologists and palaeontologists from nine countries were participants in the first international conference on "Post-Palaeozoic Bryozoa" held at the University of Stockholm, Sweden, during May 24-31, 1965, with Ivar Hessland and the Geological Institute as hosts. To assure continuation of frequent and informal exchange of information, ideas, and techniques, the conferees established the International Bryozoology Associa. tion, membership in which is open to all workers engaged in research on Bryozoa, Palaeozoic as well as post-Palaeozoic. Plans are being made for a second conference in 1968. The Stockholm conference included four days of informal discussion (led by A. H. Cheetham) of morphology, systematics, biometrics, ecology-palaeoecology, and stratigraphy of post-Palaeozoic Bryozoa and four days of collecting (led by Sten Schager and Ole Berthelsen) of Bryozoa from Senonian-Danian deposits in southern Sweden (Scania) and eastern Denmark (Zealand). Further information about the International Bryozoology Association or the Proceedings of the Stockholm conference can be obtained from A. H. Cheotham, Geological Institute, Kungstensgatan 45, Stockholm Va.; or from P. L. Cook, Department of Zoology, British Museum (Natural History), London, S.W.7.

\section{The Official University of the Congo at Elisabethville}

The July 1965 issue of Publications of the Official University of the Congo at Elisabethville contains an "Introduction to the Study of Economic Development: General Theories" by A. Cecchella, who describes representative theories of the evolution of economic thought on problems of development (Publications de l'Université Officielle du Congo d̀ Elisabethville, 8. Introduction à l'Etude du Développement Economique les Théories Générales, by Aldo Cecchella. Pp. 156. Elisabethville: Université Officielle du Congo à Elisabethville, 1965). There are four chapters. The first deals with economic development in the classic thought of J. B. Say, D. Ricardo and R. Malthus, and the second with the Marxist analysis of economic development. The third is directed to the work of J. Schumpeter and the fourth to the Keynesian analysis of modern theories of economic development.

\section{Announcements}

DR. F. M. Lever has been appointed manager of the Research Laboratories of Johnson, Matthey and Co., Ltd. He succeeds Dr. J. C. Chaston, who has retired from the Company. For the past eighteen years Dr. Lever has been head of Chemical and Extraction Metallurgy Research in the Laboratories.

Mr. P. M. J. Woodhead, senior scientific officer at the Fisheries Laboratories of the Ministry of Agriculture, Fisheries and Food, Lowestoft, has been appointed to the position of scientific and administrative officer at the Heron Island Research Station of the Great Barrier Reef Committee in Queensland, by the University of Queens. land.

THE second edition of the "Biographical Index of Members, Correspondents and Associates of the Royal Academy of Belgium" covers the years 1769-1963, correcting and completing the first edition published in 1948 (Index Biographique des Membres, Correspondants et Associés de l'Académie Royale de Belgique de 1769 a 1963. Pp. 299. Bruxelles: Académie Royale des Sciences, des Lettres et des Beaux-Arts de Belgique, 1964). The entries indicate the field of work of the member; for deceased members, reference is given to obituary notices or other tributes.

THE Annals of the Library Association, $187 \%$ to 1960 , edited on behalf of the Library History Group by W. A.
Munford, is a chronological record of the main events affecting the work of the Association since its foundation in 1877 (Pp. 128. London: The Library Association, 1965. 22s.; L.A. members, $16 s .6 d$.). Mainly of interest to librarians, it includes dates of publication of certain reports, books or pamphlets which may be of wider utility.

A. Symposium on "Cellular Plastics", the next in the series of Borough Polytechnic symposia on "Plastics and Polymer Technology", will be held at the Borough Polytechnic during November 4-5. Further information can be obtained from the Secretary, Borough Polytechnic, Borough Road, London, S.E.1.

A Celebration conference, to mark the 200th anniversary of the founding of the Freiberg Mining Academy in East Germany, will be held at the Academy during November 9-14. Further information can be obtained from Mardie Henry, Lex Hornsby and Partners, Ltd., Wellington House, 125 Strand, London, W.C.2.

A ONE-DAY conference on "Access to Information", to discuss the implications of a national bibliographical centre and any other ideas which might improve access to information, will be held in the Beveridge Hall, Senate House, University of London, on October 26. Further information can be obtained from the Research Officer, Library Association, Malet Place, London, W.C.1.

A meeting of the Photobiology Group will be held at the Chester Beatty Research Institute, London, on October 27. The programme will include a paper and conversazione on monochromators for photobiology. Further information can be obtained from Dr. J. D. Moreland, Institute of Ophthalmology, Judd Street, London, W.C.1.

THE eighteenth annual conference and exhibit on "Engineering in Medicine and Biology", sponsored by the Institute of Electronic and Electrical Engineers and the Instrument Society of America, with participation of the American Society of Mechanical Engineers, will be held in Philadelphia during November 10-12. Further information can be obtained from Dr. H. P. Schwan, University of Pennsylvania, Philadelphia, Ponnsylvania.

THE third international conference on "Hyperbaric Medicine", sponsored jointly by the Duke University Medical Center and the Committee on Hyperbaric Oxygenation of the National Academy of SciencesNational Research Council, will be held in Durham, North Carolina, during November 17-20. Further information can be obtained from the Secretariat, Box 2928, Duke University Medical Center, Durham, North Carolina.

The annual Pittsburgh Diffraction Conference will be held at the Mellon Institute, Pittsburgh, during November $3-5$. The programme will includo (1) special sessions on motals, ceramies, structuros, crystal physics (lattice dynamics and crystalline imperfections) and instrumentation and techniques, and (2) a symposium on "Texture and Preferred Orientation in Polymers". Furthor information can be obtained from Paul A. Flinn, Carnegie Institute of Technology, Pittsburgh, Pennsylvania 15213.

ERratum. In the communication entitled "Response of 'Time-dependent Materials to Oscillatory Motion" by Dr. J. Harris, which was published on p. 744 of the August 14, 1965, issue of Nature, equation (5) should. road as follows:

$$
M\left(t-t^{\prime}\right)=\int_{0}^{\infty} \frac{R(\mathrm{II})}{\mathrm{II}} \exp -\left(\frac{\left[t-t^{\prime}\right]}{\mathrm{II}} \mathrm{dII}\right)
$$

